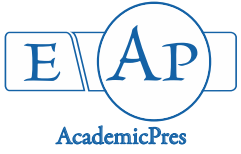

Onoja SO et al. (2021)

Notulae Scientia Biologicae 13(1):10886

DOI: $10.15835 / \mathrm{nsb} 13110886$

Research Article

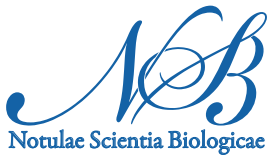

\title{
Anti-ulcer property of methanol fraction of Callichilia subsessilis leaf extract in albino rats
}

\author{
Samuel O. ONOJA ${ }^{1 *}$, Gladys C. EZEH ${ }^{2}$, Nkeiruka E. UDEH ${ }^{1}$, \\ Chinyere B. C. IKPA ${ }^{3}$, Daniel UGOJI ${ }^{1}$, Jessica I. UKWUEZE ${ }^{1}$, \\ Kelechi G. MADUBUIKE ${ }^{1}$, Patrick E. ABA ${ }^{4}$, Maxwell I. EZEJA ${ }^{1}$

\begin{abstract}
${ }^{1}$ Michael Okpara University of Agriculture, Department of Veterinary Physiology and Pharmacology, Umudike, PMB 7267, Abia State,Nigeria; onoja.samuel@mouau.edu.ng (*correspondingauthor); samonreal@yahoo.com; ukwueze.ifunanya@mouau.edu.ng, udeh.nkeiruka@mouau.edu.ng,danny.ugoji@gmail.com,madubuike.kelechi@mouau.edu.ng,maxwell.ezeja@gmail.com ${ }_{2}^{2}$ Alex Ekwueme Federal University, Department of Agriculture, Ndufu Alike-Ikwo, Ebonyi State, Nigeria; joanezeh1@gmail.com ${ }^{3}$ Imo State University, Department of Chemistry, P.M.B 2000, Owerri, Imo State, Nigeria; ikpacbc@gmail.com ${ }^{4}$ University of Nigeria, Department of Veterinary Physiology and Pharmacology, Nsukka, Nigeria; patrick.aba@unn.edu.ng
\end{abstract}

\begin{abstract}
Peptic ulcer is one of the major causes of morbidity and mortality worldwide. It is treated with herbal preparations in developing countries. This study investigated the anti-ulcer property of methanol fraction of Callichilia subsessilis leaf in albino rats. Methanol extract prepared through the cold maceration method was partitioned into chloroform and methanol fraction using a separating funnel. The methanol fraction of Callichilia subsessilis (MFCS) was concentrated in vacuo using a rotary evaporator. The acute toxicity was determined using the brine shrimp lethality test and the up-and-down method at a dose limit of $2000 \mathrm{mg} / \mathrm{kg}$. The anti-ulcer activity of MFCS was evaluated at the doses of $12.5,25$ and $50 \mathrm{mg} / \mathrm{kg}$ using indomethacin-and ethanol-induced ulcer models. Misoprostol was used as a reference standard. The ulcer score, index and severity were determined using standard methods. Isolated rabbit jejunum tissue in Tyrode's solution was used to establish the possible mechanism of anti-ulcer activity of MFCS. The $\mathrm{LC}_{50}$ and $\mathrm{LD}_{50}$ of MFCS were greater than $10,000 \mathrm{ppm}$ and 2,000 mg/kg respectively. The MFCS exhibited significant $(\mathrm{p}<0.05)$ dose-dependent anti-ulcer activity in all the ulcer models used. The MFCS $(25 \mathrm{mg} / \mathrm{kg})$ produced $52 \%$ and $41.33 \%$ inhibition of ulcer index in the indomethacin- and ethanol-induced ulcer models respectively. In the isolated tissue model, MFCS caused significant $(p<0.05)$ relaxation of the rhythmic contraction of the isolated rabbit jejunum and partially inhibited acetylcholine- and histamine-induced contraction of the jejunal smooth muscles. In conclusion, MFCS exhibited anti-ulcer (antihistaminic and anticholinergic) effects. This study justified the use of Callichilia subsessilis leaves in traditional medicine as an anti-ulcer remedy.
\end{abstract}

Keywords: anticholinergic receptor; antihistamine; anti-ulcer; Callichilia subsessilis; ethanol; indomethacin

Received: 25 Jan 2021. Received in revised form: 16 Feb 2021. Accepted: 24 Feb 2021. Published online: 02 Mar 2021.

From Volume 13, Issue 1, 2021, Notulae Scientia Biologicae journal will use article numbers in place of the traditional method of continuous pagination through the volume. 


\section{Introduction}

Peptic ulcer is referred to as a peptic injury of the digestive tract and occurs mainly in the stomach or upper duodenum, but can also be found in the lower esophagus and Meckel's diverticulum (Albaqawi et al., 2017; Lanas and Chan, 2017; Sayehmiri et al., 2018). It is a break in the mucosal lining of the gastrointestinal tract. The global prevalence is estimated at 4-15\% and an annual incidence rate of 0.1-0.3\% (Lanas and Chan, 2017; Sayehmiri et al., 2018). It is caused by an imbalance in the defensive and offensive factors of the gastrointestinal mucosa integrity (Sayehmiri et al., 2018). The defensive factors are mucus, bicarbonate, blood fluids, prostaglandins and antioxidants, while the offensive factors are excessive gastric acid, Helicobacter pylori and free radicals. The common causes of peptic ulcer are $H$. pylori and indiscriminate use of non-steroidal antiinflammatory drugs. Some of the predisposing factors are cigarette smoking, Behcet's disease, Zollinger-Ellison syndrome, Crohn's disease and stress (Albaqawi et al., 2017). Some of the associated complications of peptic ulcer are gastric bleeding (which occur in $15 \%$ of patients), perforation and obstruction. The clinical management of peptic ulcer involves the use of drugs like antacids, proton pump inhibitors, histamine $\left(\mathrm{H}_{2}\right)$ receptor antagonists, cytoprotective agents and antibiotics (Paguigan et al., 2014). Peptic ulcer is more effectively treated with multiple drug combinations. One of the commonly used combinations is a proton pump inhibitor plus amoxicillin plus clarithromycin with or without a cytoprotective agent (bismuth or misoprostol) (Fallone et al., 2016; Lanas and Chan, 2017). There is a growing interest in the use of herbal preparation in the management of peptic ulcer and other diseases (Balan etal., 2014; Zabidi et al., 2012). World Health Organization (WHO) estimated that $80 \%$ of the world population depend on herbal medicine for their primary healthcare needs (Raskin et al., 2002). The increasing use of herbal preparation in ulcer management is attributed to the resistance of $H$. pylori to most antibiotics and other factors such as; unavailability, high cost, and side effects of orthodox medicines (Malfertheiner et al., 2017). One of the commonly used plants in herbal medicine preparation is Callichilia subsessilis.

Callichilia subsessilis (Benth.) Stapf belongs to the family Apocynaceae. It is known as "Aba-nua" in Ghana, "Vaimi" in Sierra Leone and "Mkpiri" in Igboland Nigeria (Burkill, 1985). The habitat is along the coast of West Africa. The infusion or decoction of the leaves is used by traditional bone setters for fracture reduction in Ozuitem, in Abia State, Nigeria. Preliminary investigation of phytochemical constituents has revealed the presence of alkaloids, saponins, flavonoids, terpenes, glycosides and tannins in the methanol extract of $C$. subsessilis leaf (Onoja et al., 2018). The anti-inflammatory, analgesic and antioxidant potential of $C$. subsessilis have also been documented (Onoja et al., 2018). The leaves of $C$. subsessilis are added in herbal infusions and/or poultice used in ulcer treatment in Southeast Nigeria (oral communication). Despite the use of $C$. subsessilis in the traditional treatment of ulcer, to the best of our knowledge, there is a dearth of information in the scientific literature on its anti-ulcer potential. Therefore, this study investigated the antiulcer activity of methanol fraction Callichilia subsessilis leaf extract in Wistar rats.

\section{Materials and Methods}

\section{Collection and authentication of plant material}

Fresh leaves of $C$. subsessilis were collected and authenticated by Mr. Ndukwe Ibeh, a taxonomist with the College of Natural Resources and Environmental Management, Michael Okpara University of Agriculture, Umudike, Nigeria. Voucher sample (MOUAU/VPP/2016/20) was deposited in the Department of Veterinary Physiology and Pharmacology of same University.

\section{Preparation of the plant extract}

The leaves were washed and sorted for any contaminant and dried under shed (on laboratory bench) before grinding into a coarse powder with a manual blender. The coarse powder was weighed with a balance 
scale, then soaked in $80 \%$ methanol in aqueous methanol in a Winchester bottle at room temperature for $48 \mathrm{~h}$ following vigorous shaken every $3 \mathrm{~h}$. Filtration was done using Whatman No 1 filter paper and the filtrate was concentrated in a hot air oven set at $40{ }^{\circ} \mathrm{C}$.

\section{Solvent-solvent partitioning}

The methanol extract of $C$. subsessilis was partitioned into methanol and chloroform fractions using a separating funnel. The two partitions/fractions were evaporated to dryness using a hot air oven. The methanol fraction of $C$. subsessilis (MFCS) was used for the study and it was stored in a refrigerator at $4{ }^{\circ} \mathrm{C}$ throughout the experiment.

\section{Brine shrimp lethality test}

The eggs of brine shrimp were collected and hatched using seawater in a small beaker after $24 \mathrm{~h}$. The active and swimming nymphs were counted with the aid of a glass capillary dropper into test tubes at 10 active larvae per test tube. The nymphaea in seawater were incubated with varied concentrations of MFCS (625, 1250, 2500, 5000 and $10000 \mathrm{ppm}$ ) in triplicates for 24 hours at room temperature. After 24 hours of incubation, the surviving nymphaea were counted and the percentage mortality was calculated as follows:

$$
\text { Percentage mortality }=\frac{\text { initial number of viable nymph }- \text { final number of viable nymph }}{\text { initial number of viable nymph }} \times \frac{100}{1}
$$

\section{Experimental animals}

Sixty albino Wistar rats (weighing average $110 \mathrm{~g}$ ) of both sexes and a rabbit obtained from the laboratory animal unit of the Department of Veterinary Physiology and Pharmacology, Michael Okpara University of Agriculture, Umudike were used in this work. The animals were acclimatized for two weeks, under standard conditions. They were housed in aluminum cages and fed with standard commercial pelleted feed (Vital feed", Nigeria) and clean drinking water was provided ad-libitum. The experimental protocol was approved by the Institutional Animal Ethics Committee of the College of Veterinary Medicine, Michael Okpara University of Agriculture Umudike (MOUAU/CVM/REC/18025).

\section{Acute toxicity test}

The up-and-down procedure with a dose limit of $2000 \mathrm{mg} / \mathrm{kg}$ was adopted (OECD, 2008). Ten (10) rats were used for the study as described by Onoja et al. (2018).

\section{Indomethacin-induced ulcer model}

The effect of the MFCS on the indomethacin-induced ulcer model was studied according to the method of Ubaka et al. (2010). Twenty-five rats were assigned to five groups (A-E; $n=5)$. Groups A and B served as negative and positive control and received distilled water $5 \mathrm{ml} / \mathrm{kg}$ and misoprostol $50 \mu \mathrm{g} / \mathrm{kg}$ body weight (BW), respectively. Groups C-E received MFCS $12.5,25$ and $50 \mathrm{mg} / \mathrm{kg} \mathrm{BM}$, respectively. The distilled water, misoprostol and MFCS were administered orally. One (1) hour post-treatment, all the rats were given indomethacin $(20 \mathrm{mg} / \mathrm{kg} \mathrm{BW})$ per os. Four hours later, all the rats were sacrificed by cervical dislocation. The stomachs were removed, ligated at both ends, inflated with $1 \%$ formalin and later submerged in $1 \%$ formalin for $24 \mathrm{~h}$. Thereafter, the stomachs were cut open along the greater curvature to view and score the ulcer lesion under the hand lens. The ulcers were scored as follows: $0=$ no ulcer, $1=$ superficial ulcer, $2=$ deep ulcer and 3 $=$ perforation. The ulcer index and percentage inhibition were calculated.

Ulcer Index $(\mathrm{UI})=\frac{(\mathrm{Un}+\mathrm{Us}+\mathrm{Up})}{10}$

Where: $\mathrm{UI}=$ ulcer index, $\mathrm{Un}=$ average number of ulcers per rat, $\mathrm{Us}=$ average severity score, $\mathrm{Up}=$ percentage of the animal with ulcer.

$$
\text { Percentage }(\%) \text { ulcer inhibition }=\frac{\text { UI }(\text { control })-\text { UI (treatment })}{\text { UI }(\text { control })} \times \frac{100}{1}
$$




\section{Ethanol-induced ulcer}

The effect of the MFCS on the ethanol-induced ulcer model was studied according to the method of Ubaka et al. (2010). Twenty-five rats were assigned to five groups (A-E; $\mathrm{n}=5)$. Groups A and B served as negative and positive control and received distilled water $5 \mathrm{ml} / \mathrm{kg}$ and misoprostol $50 \mu \mathrm{g} / \mathrm{kg} \mathrm{BW}$, respectively. Groups C-E received MFCS 12.5, 25 and $50 \mathrm{mg} / \mathrm{kg} \mathrm{BW}$, respectively. The distilled water, misoprostol and MFCS were administered orally. One (1) hour post-treatment, all rats were given indomethacin $(20 \mathrm{mg} / \mathrm{kg}$ $\mathrm{BW}$ ) per os. Four hours later, all the rats were sacrificed for cervical dislocation. The stomachs were processed and ulcer score, ulcer index and percentage inhibition were determined as described above.

\section{Isolated rabbit jejunum tissue model}

An adult rabbit was sacrificed (by stunning) after $24 \mathrm{~h}$ fast. A segment of the jejeunum (about $3 \mathrm{~cm}$ long) was cut out from the remaining length of the organ and the adhering mesentery was trimmed off. The tissue was then suspended in a $35 \mathrm{ml}$ organ bath containing Tyrode's solution $\left(\mathrm{NaCl} 8.00 \mathrm{gl}^{-1}, \mathrm{KCl} 0.02 \mathrm{gl}^{-1}, \mathrm{CaCl}_{2}\right.$ $0.20 \mathrm{gl}^{-1}, \mathrm{NaHCO}_{3} 1.00 \mathrm{gl}^{-1}, \mathrm{NaH}_{2} \mathrm{PO}_{4} 1.00 \mathrm{gl}^{-1}, \mathrm{MgCl}_{2} 0.10 \mathrm{gl}^{-1}$, glucose $\left.2.00 \mathrm{gl}^{-1}, \mathrm{MgSO}^{-} . \mathrm{H}_{2} \mathrm{O} 2.0 \mathrm{gl}^{-1}\right)$ with the lower end of the tissue segment tied to the bottom of the organ bath chamber and the other end tied to a transducer. The set up was maintained at $37^{\circ} \mathrm{C}$ and aerated with air. The effect of acetylcholine and MFCS were tested on the strips of rabbit jejunum both before and after antagonizing their cholinergic and histaminic receptors. Digital physiography was used to record the pre- and post-treatment contraction of the suspended jejunum segment.

Final bath concentration $(\mathrm{FBC})=\frac{\mathrm{U} \times \mathrm{C}}{\mathrm{V}}$

Where: $\mathrm{U}=$ volume added, $\mathrm{C}=$ concentration of extract/drug, $\mathrm{V}=$ volume of organ bath

\section{Histopathological examination}

The stomach tissues of rats of indomethacin-induced ulcer models were fixed in $10 \%$ formal saline, processed using a standard protocol, sectioned and stained with hematoxylin and eosin $(\mathrm{H} \& \mathrm{E})$ stained. The photomicrographs of the stomach tissues were captured under a digitallight microscope.

\section{Statistical analysis}

Data generated were presented as mean \pm SEM and analyzed using one-way-analysis of variance (ANOVA) and post-hoc comparisons were done using KruskalWallis test on SPSS version 22. Values of $P<$ 0.05 were considered significant.

\section{Results}

Brine shrimp let hality test

The MFCS at 10,000 ppm caused 30\% mortality of the nymph. The $\mathrm{LC}_{50}$ of the MFCS was greater than $10,000 \mathrm{ppm}$ (Figure 1).

\section{Acute oral toxicity test}

The MFCS elicited neither signs of toxicity nor mortality in the treated rats at $2000 \mathrm{mg} / \mathrm{kg}$. The $\mathrm{LD}_{50}$ of the MFCS was thus greater than $2000 \mathrm{mg} / \mathrm{kg}$.

\section{Effects of MFCS against indomethacin-induced gastric ulcer}

The MFCS and misoprostol elicited significant $(\mathrm{p}<0.05)$ reductions in ulcer numbers, scores and index in the treated rats relative to the distilled water treated rats. The MFCS produced dose-dependent effects up to $25 \mathrm{mg} / \mathrm{kg}$ body weight. The optimum effect of the MFCS was exhibited at $25 \mathrm{mg} / \mathrm{kg}$ (Table 1). 


\section{Effects of MFCS against ethanol-induced gastric ulcer}

The MFCS and misoprostol caused a significant $(\mathrm{p}<0.05)$ decrease in the ulcer index of the treated rats compared to the distilled water treated group. The gastroprotective effects of the MFCS were comparable to the effect of misoprostol (Table 2).

\section{Gross morphology of stomach of indomethacin-induced gastric ulcer in rats}

The gross morphology of the stomach of the indomethacin-induced gastric ulcer is shown in Figure 2. The letter ' $U$ ' denotes the area of ulceration. The distilled water treated rats (Figure 2A) had more area of ulceration relative to other treatment groups. The MFCS $(25 \mathrm{mg} / \mathrm{kg}$ ) treated group (Figure 2D) had no ulcer lesion.

Table 1. Effects of MFCS against indomethacin-induced gastric ulcer

\begin{tabular}{|c|c|c|c|c|}
\hline Treatment & Ulcer number & Ulcer score & Ulcer index & \% inhibition \\
\hline Distilled water $5 \mathrm{ml} / \mathrm{kg}$ & $21.40 \pm 7.93$ & $28.60 \pm 11.16$ & $13.00 \pm 1.90$ & - \\
\hline Misoprostol $50 \mu \mathrm{g} / \mathrm{kg}$ & $8.00 \pm 5.41^{*}$ & $10.00 \pm 5.92^{*}$ & $7.80 \pm 1.12^{*}$ & 40 \\
\hline MFCS $12.5 \mathrm{mg} / \mathrm{kg}$ & $6.75 \pm 5.15^{*}$ & $7.25 \pm 5.64^{*}$ & $7.02 \pm 0.82^{*}$ & 46 \\
\hline MFCS $25 \mathrm{mg} / \mathrm{kg}$ & $1.20 \pm 0.58^{*}$ & $1.20 \pm 0.58^{*}$ & $6.24 \pm 0.11^{*}$ & 52 \\
\hline MFCS $50 \mathrm{mg} / \mathrm{kg}$ & $4.20 \pm 1.98^{*}$ & $4.20 \pm 1.98^{*}$ & $8.84 \pm 0.39^{*}$ & 32 \\
\hline
\end{tabular}

${ }^{*} \mathrm{P}<0.05$ when compared with distilled water treated group, MFCS $=$ methanol fraction of Callichilia subsessilis

Table 2. Effects of MFCS against ethanol-induced gastric ulcer

\begin{tabular}{|c|c|c|c|c|}
\hline Treatment & Ulcer number & Ulcer score & Ulcer index & \% inhibition \\
\hline Distilled water $5 \mathrm{ml} / \mathrm{kg}$ & $5.00 \pm 3.13$ & $5.90 \pm 3.14$ & $7.09 \pm 0.65$ & - \\
\hline Misoprostol $50 \mu \mathrm{g} / \mathrm{kg}$ & $0.60 \pm 0.40$ & $0.60 \pm 0.40^{*}$ & $4.12 \pm 0.08^{*}$ & 41.71 \\
\hline MFCS $12.5 \mathrm{mg} / \mathrm{kg}$ & $1.80 \pm 0.92$ & $2.00 \pm 1.05$ & $4.38 \pm 0.20^{*}$ & 38.22 \\
\hline MFCS $25 \mathrm{mg} / \mathrm{kg}$ & $0.80 \pm 0.49$ & $0.80 \pm 0.49^{*}$ & $4.16 \pm 0.10^{*}$ & 41.33 \\
\hline MFCS $50 \mathrm{mg} / \mathrm{kg}$ & $1.40 \pm 0.75$ & $1.40 \pm 0.75$ & $4.28 \pm 0.15^{*}$ & 39.63 \\
\hline
\end{tabular}

${ }^{*} \mathrm{P}<0.05$ when compared with distilled water treated group, MFCS $=$ methanol fraction of Callichilia subsessilis

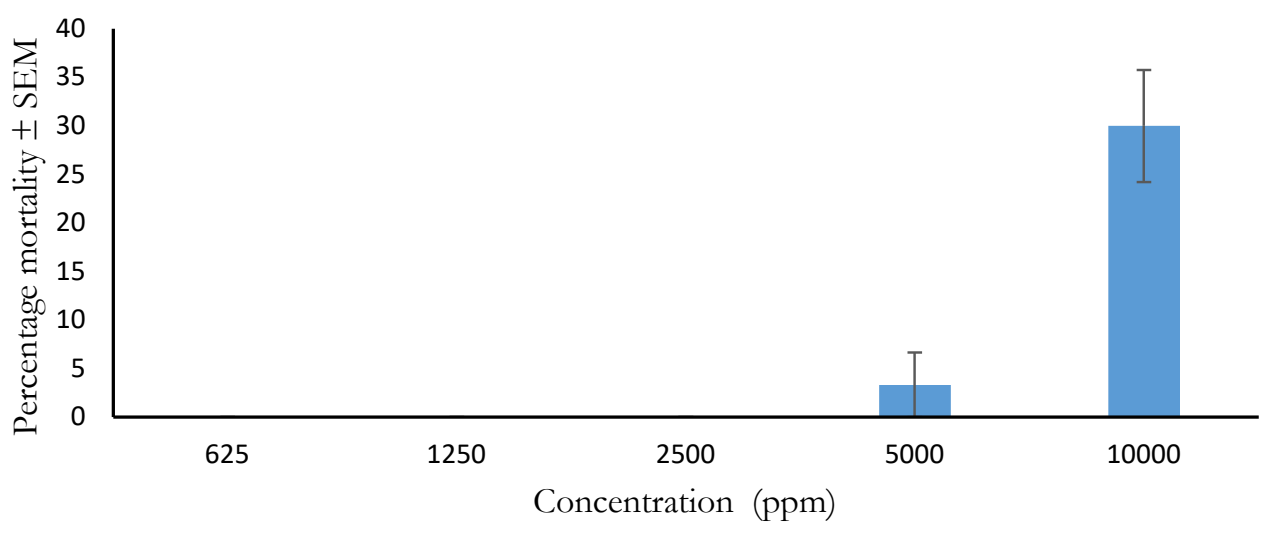

Figure 1. Brine shrimp's lethality test

MFCS = methanol fraction of Callichilia subsessilis, $\mathrm{ppm}=$ parts per million 

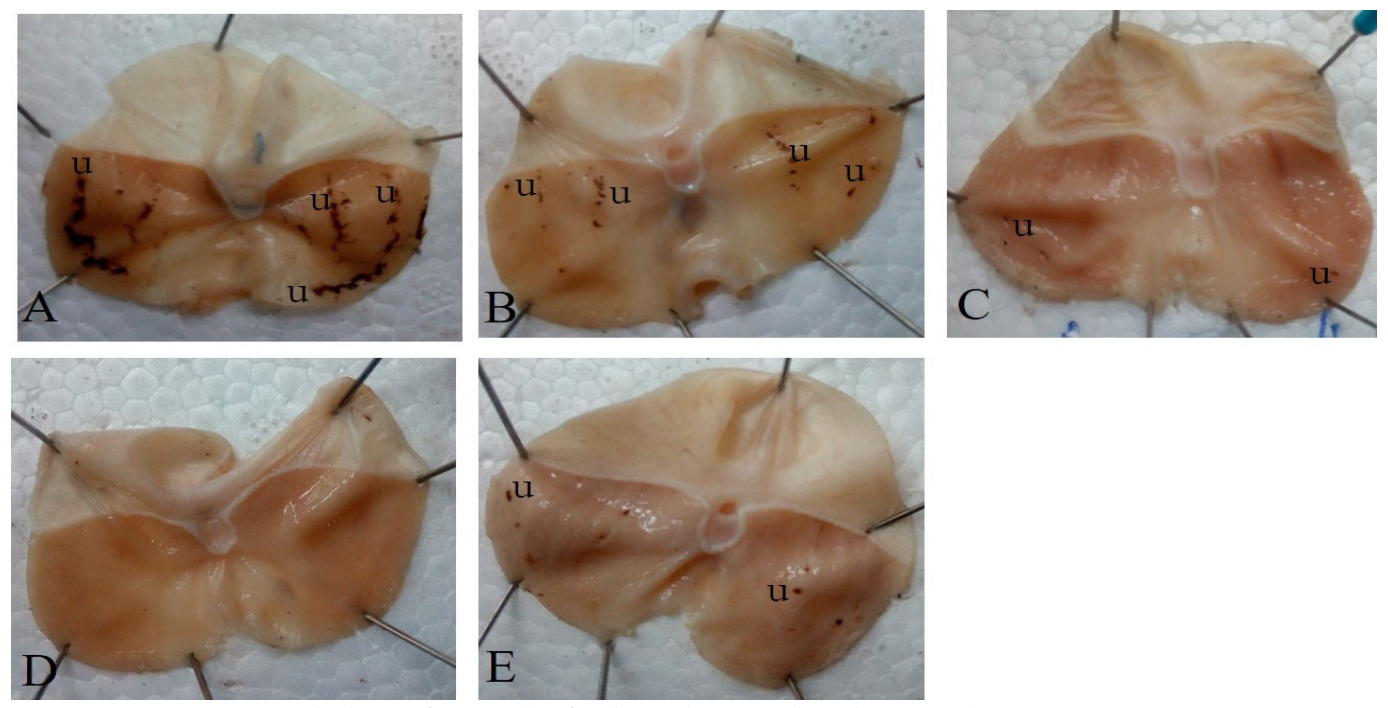

Figure 2. Gross morphology of stomach of indomethacin-induced gastric ulcer in rats

Legend: "U" = ulcer lesion, A = Distilled water $5 \mathrm{ml} / \mathrm{kg}, \mathrm{B}=$ Misoprostol $50 \mu \mathrm{g} / \mathrm{kg}, \mathrm{C}=$ MFCS $12.5 \mathrm{mg} / \mathrm{kg}, \mathrm{D}=\mathrm{MFCS}$

$25 \mathrm{mg} / \mathrm{kg}, \mathrm{E}=\operatorname{MFCS} 50 \mathrm{mg} / \mathrm{kg}$

\section{Histological sections of the stomach of indomethacin-induced gastric ulcer in rats}

The photomicrograph of the histological sections of the stomach of indomethacin-induced gastric ulcer is presented in Figure 3. The letters ' $U$ ' and ' $M$ ' denotes ulcer lesion and mucosa layer, respectively. Figure 3A (distilled water treated group) had deeper and larger areas of ulceration relative to other treatment groups. Figure 3E (50 mg/kg MFCS treated group) had smaller and shallower areas of ulceration whereas Figures 3B$3 \mathrm{D}$ showed normal stomach section.
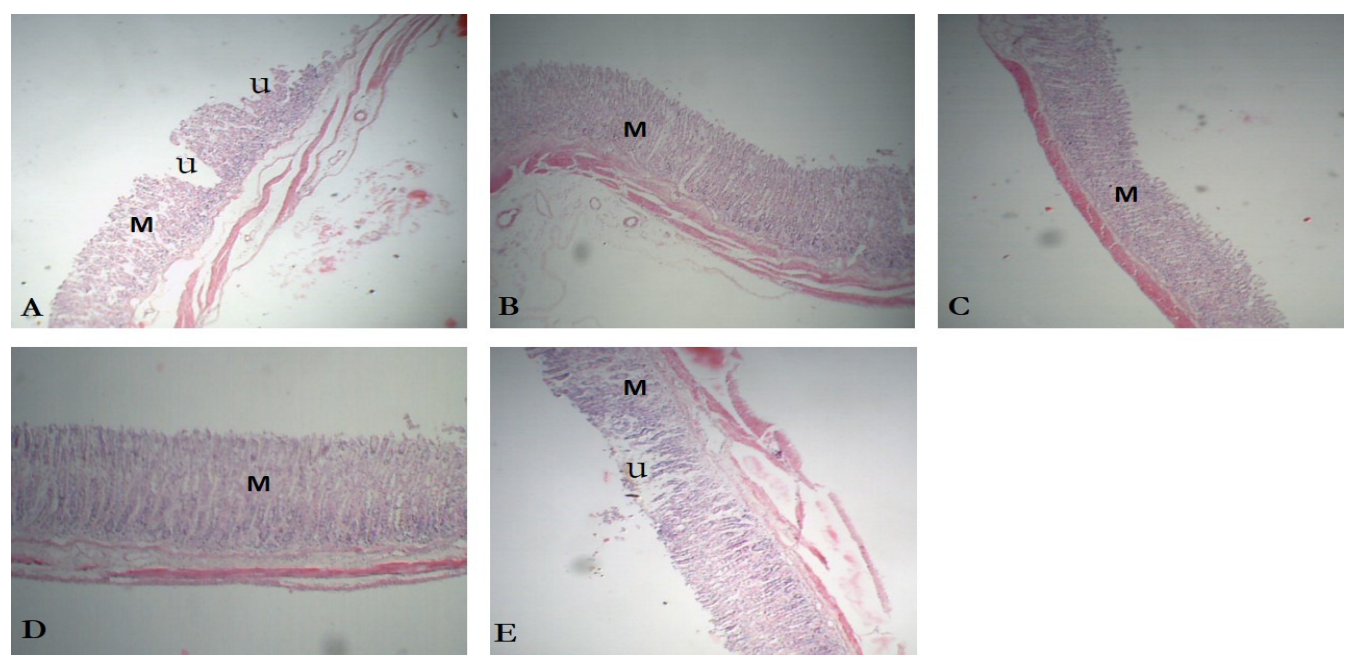

Figure 3. Histological section of the stomach of indomethacin-induced gastric ulcer in rats Legend: "U" = ulcer lesion, "M" = mucosa, A = Distilled water $5 \mathrm{ml} / \mathrm{kg}, \mathrm{B}=$ Misoprostol $50 \mu \mathrm{g} / \mathrm{kg}, \mathrm{C}=\mathrm{MFCS} 12.5$ $\mathrm{mg} / \mathrm{kg}, \mathrm{D}=$ MFCS $25 \mathrm{mg} / \mathrm{kg}$, E = MFCS $50 \mathrm{mg} / \mathrm{kg}$

\section{Gross morphology of stomach of ethanol-induced gastric ulcer in rats}

The gross morphology (photograph) of the stomach of ethanol-induced ulcer in rats are present in Figure 4. Figure 4A (distilled water-treated group) showed larger areas of ulceration relative to the other treatment groups, while Figure 4C and 4E, MFCS 12.5 and $50 \mathrm{mg} / \mathrm{kg}$ treated groups, respectively showed fewer 
areas of ulceration relative to the distilled water treated group. Misoprostol and MFCS $25 \mathrm{mg} / \mathrm{kg}$ treated groups (Figure 4B and 4D) showed no area of ulceration.
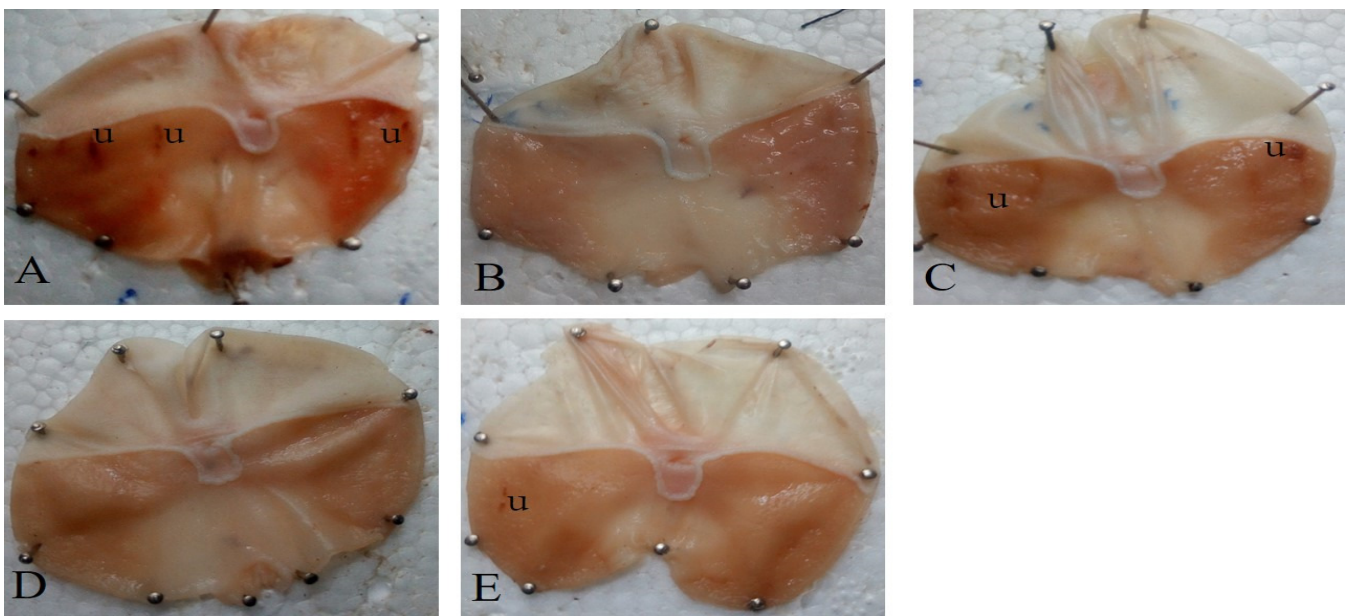

Figure 4. Gross morphology of stomach of ethanol-induced gastric ulcer in rats Legend: "U" = ulcer lesion, A = Distilled water $5 \mathrm{ml} / \mathrm{kg}, \mathrm{B}=$ Misoprostol $50 \mu \mathrm{g} / \mathrm{kg}, \mathrm{C}=$ MFCS $12.5 \mathrm{mg} / \mathrm{kg}, \mathrm{D}=$ MFCS $25 \mathrm{mg} / \mathrm{kg}, \mathrm{E}=\operatorname{MFCS} 50 \mathrm{mg} / \mathrm{kg}$

\section{Effects of MFCS against isolated rabbit jejunum}

The MFCS elicited $(\mathrm{p}<0.05)$ concentration-dependent decrease in the amplitude of a spontaneously contracting rabbit jejunum in Tyrode's solution. It also partially inhibited acetylcholine- and histamineinduced increase in the contraction of a rhythmic contracting rabbit jejunum (Figure 5).

\section{Discussion}

This study interrogated the anti-ulcer property of MFCS and its possible mechanism of action. MFCS reduced $(\mathrm{p}<0.05)$ ulcer lesion in indomethacin- and ethanol-induced gastric ulcer in rats and also diminished the rhythmic contraction of isolated rabbit jejunum in a Tyrode's solution. It partially inhibited histamine- and acetylcholine-induced contraction of the smooth muscle of isolated rabbit jejunum.

Ethanol induces gastric ulcer via the elevated release of gastric acid, free radical and pepsin, as well as declined bicarbonate and mucus production (Sistani et al., 2019). These conditions make the gastric mucosa vulnerable to the deleterious effects of the offensive factors that predispose to gastric ulceration (Sahoo et al., 2016). Indomethacin causes gastric ulceration via inhibition of cyclooxygenase activity, declined prostaglandin, mucus and bicarbonate production, reduced gastric blood flow and elevated free radical release (Sabiu et al., 2015). The decreased ulcer lesions in the MFCS-treated groups suggest that some of the biochemical processes implicated in ethanol- and indomethacin-induced ulcer were inhibited and MFCS possess anti-ulcer activity (Sabiu et al., 2015; Sahoo et al., 2016; Sistani et al., 2019).

Free radicals and lipid peroxidation play a pivotal role in the pathogenesis of indomethacin- and ethanolinduced gastric ulcer (Sabiu et al., 2015; Sahoo et al., 2016; Sistani et al., 2019). Antioxidants mop up free radicals and inhibit lipid peroxidation thus, useful in the amelioration of gastric ulcer (Salami et al., 2018). The anti-ulcer activity of MFCS could be linked to its antioxidant potentials. The anti-ulcer effects of Punica granatum, Aegle marmelos and Allium sativum were attributed to their antioxidant properties (Harsha et al., 2017). 


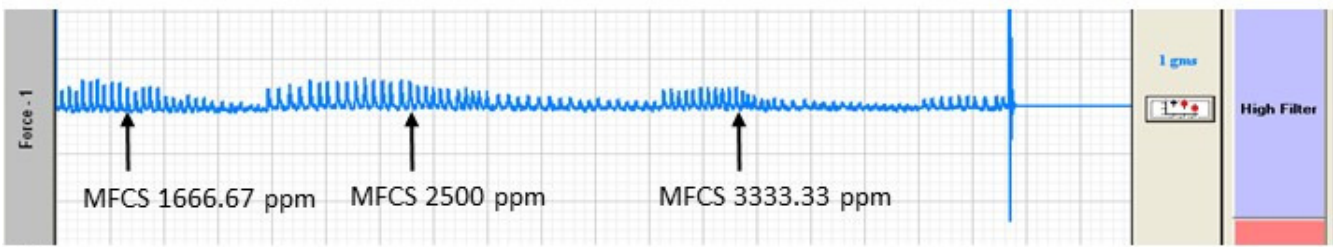

$5 A$

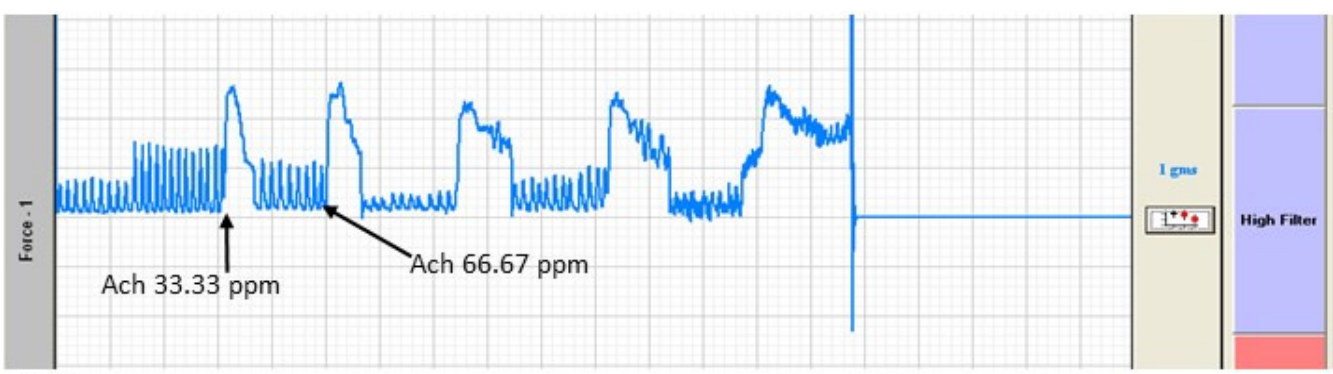

5B

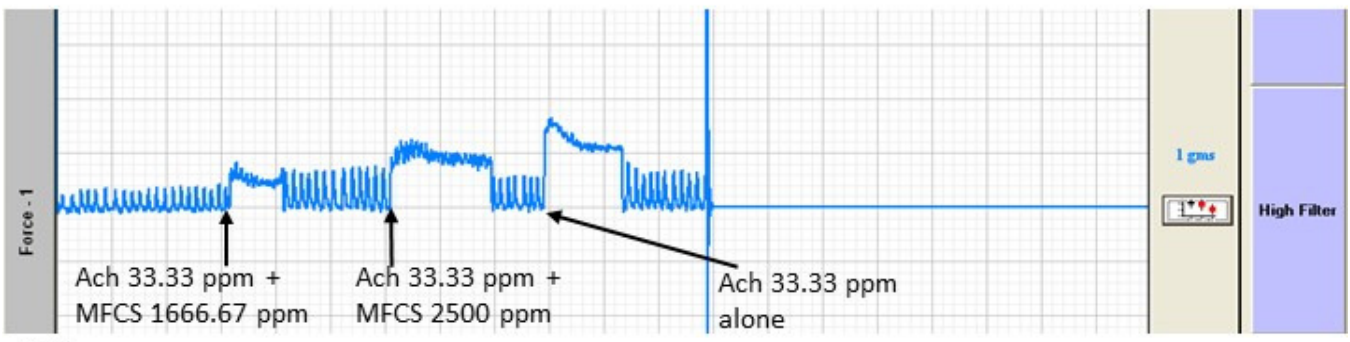

5C

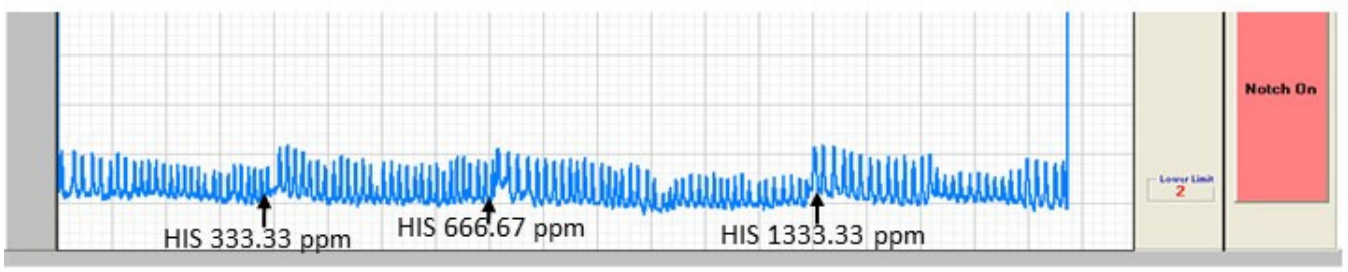

5D

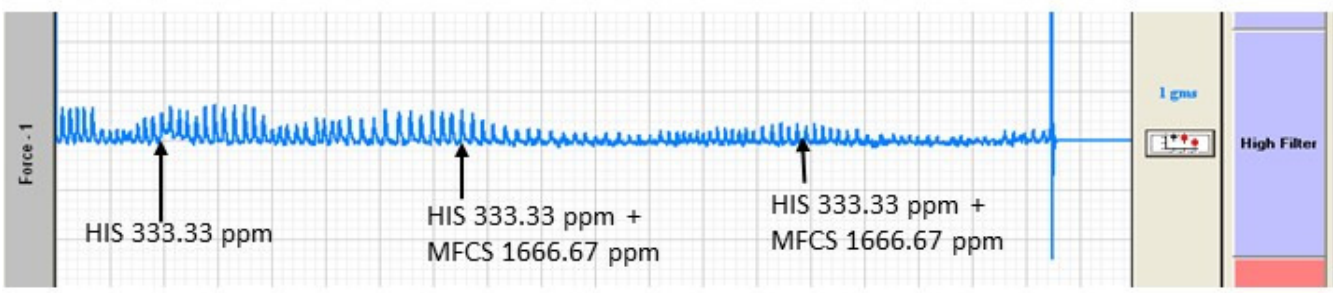

$5 \mathrm{E}$

Figure 5. Effects of MFCS against isolated rabbit jejunum

Legend: $5 \mathrm{~A}=$ MFCS alone, 5B = acetylcholine (Ach) alone, 5C = MFCS and acetylcholine (Ach), 5D = histamine (HIS) alone, $5 \mathrm{E}=\mathrm{MFCS}$ and histamine (HIS), MFCS $=$ methanol fraction of Callichilia subsessilis 
The MFCS partially inhibited histamine and acetylcholine-induced contraction of isolated rabbit jejunum. This suggests that it possesses antihistaminic and anticholinergic properties and would act as an antisecretory agent (da Silva et al., 2018). Histamine $\left(\mathrm{H}_{2}\right)$ and acetylcholine receptor abound in the intestinal mucosa and are involved in the synthesis and secretion of gastric acid as well as control of gastrointestinal motility (Takeuchi et al., 2016). Antisecretory agents impair the activity of hydrogen-potassium adenosine triphosphatase $\left(\mathrm{H}^{+}-\mathrm{K}^{+}\right.$ATPase) and $\mathrm{H}_{2}$ receptor which are involved in the secretion of gastric acid (Lundell, 2015; Takeuchi et al., 2016). Histamine $\left(\mathrm{H}_{2}\right)$ receptor antagonists (cimetidine and ranitidine) are employed in the treatment of gastric ulcer (Harsha et al., 2017). The antihistaminic effect of one of the constituents of MFCS (cyclohexanone) has been documented (Nabil et al., 2018). Anti-ulcer effects of Ficus glomerata and Solanum nigrum is attributed to the inhibition of $\mathrm{H}^{+}-\mathrm{K}^{+}$ATPase (Harsha et al., 2017). Anticholinergic agents delay gastrointestinal emptying time and decrease the secretion of gastric acid and pepsin, thus ameliorate gastric ulcer.

The anti-ulcer activity of MFCS compared favorably with misoprostol and this suggests that they might have an identical mechanism of action. Misoprostol is a prostaglandin (PGE-1) analogue that stimulate mucus and bicarbonate production. It also protects the epithelial layer integrity by eliciting vasodilation and enhanced mucosal blood circulation (Sałaga and Mosińska, 2017). The MFCS might have stimulated prostaglandins production.

\section{Conclusions}

This study validated the use of Callichilia subsessilis leaf in the traditional treatment of gastric ulcer. It might have multiple mechanisms of action such as antihistaminic, anticholinergic, enhanced prostaglandin production and antioxidation effects. We recommend further studies geared towards isolation of active principle and elucidation of the mechanism of action.

\section{Authors' Contributions}

SOO, GCE and DU were involved in the conceptualization, design, execution, draft and review of the manuscript; $\mathrm{CBCI}$ drafted and review the manuscript; JIU, KGM and PEA participated in the design, sourcing of material, statistical analysis and review of manuscript while NEU and MIE were involved in the supervision, review and editing of the manuscript.

All authors read and approved the final manuscript.

\section{Ethical approval}

The experimental protocol was approved by the institutional Animal Ethics Committee of the College of Veterinary Medicine, Michael Okpara University of Agriculture Umudike.

\section{Acknowledgements}

The authors are grateful to Mr. Ndukwe Ibeh for the identification of the plant. 


\section{Conflict of Interests}

The authors declare that there are no conflicts of interest related to this article.

\section{References}

Albaqawi AS, el-Fetoh NM, Alanazi RF, Alanazi NS, Alrayya SE, Alanazi AN, ... Ali WM (2017). Profile of peptic ulcer disease and its risk factors in Arar, Northern Saudi Arabia. Electronic Physician 9(11):5740-5745. http://dx.doi.org/10.19082/5740

Balan T, Mohd. Sani MH, Suppaiah V, Mohtarrudin N, Suhaili Z, Ahmad Z, Zakaria ZA (2014). Antiulcer activity of Muntingia calabura leaves involves the modulation of endogenous nitric oxide and nonprotein sulfhydryl compounds. Pharmaceutical Biology 52(4):410-418. https://doi.org/10.3109/13880209.2013.839713

da Silva LM, de Moura BL, Crestani S, de Souza P, Dartora N, de Souza LM, ... de Paula WMF (2018). Acid-gastric antisecretory effect of the ethanolic extract from Arctium lappa L. root: role of $\mathrm{H}+, \mathrm{K}+$-ATPase, $\mathrm{Ca} 2+$ influx and the cholinergic pathway. Inflammopharmacology 26(2):521-530. https://doi.org/10.1007/s10787-017-0378-4

Fallone CA, Chiba N, van Zanten SV, Fischbach L, Gisbert JP, Hunt RH, ... Marshall JK. The Toronto consensus for the treatment of Helicobacter pylori infection in adults. Gastroenterology 151(1):51-69. https://doi.org/10.1053/j.gastro.2016.04.006

Harsha C, Banik K, Bordoloi D, Kunnumakkara AB (2017). Antiulcer properties of fruits and vegetables: A mechanism based perspective. Food and Chemical Toxicology 108:104-119. https://doi.org/10.1016/j.fct.2017.07.023

Lanas A, Chan FK (2017). Peptic ulcer disease. The Lancet 390(10094):613-624. https://doiorg/10.1016/S01406736(16)32404-7

Lundell L (2015). The physiological background behind and course of development of the first proton pump inhibitor. Scandinavian Journal of Gastroenterology 50(6):680-684. https://doi.org/10.3109/00365521.2015.1013981

Malfertheiner P, Megraud F, O'morain CA, Gisbert JP, Kuipers EJ, Axon AT, ... Hunt R (2017). Management of Helicobacter pylori infection-the Maastricht V/Florence consensus report. Gut 66(1):6-30. http://dx.doi.org/10.1136/gutjinl-2016-312288

Nabil S, Abd El-Rahman SN, Al-Jameel SS, Elsharif AM (2018). Conversion of curcumin into heterocyclic compounds as potent anti-diabetic and anti-histamine agents. Biological and Pharmaceutical Bulletin 41(7):10711077. https://doi.org/10.1248/bpb.b18-00170

Onoja SO, Ikwuagwu EO, Ezeigbo II, Madubuike KG, Omeh YN, Anaga AO, Ezeja MI (2018). Preliminary investigation of the possible antiinflammatory and antioxidant activities of extract of Callichilia subsessilis Stapf. (Apocynaceae). Tropical Journal of Natural Product Research 2(1):34-37. https://doi.org/10.26538/tjnpr/v2i1.7

Paguigan ND, Castillo DHB, Chichioco-Hernandez CL (2014). Anti-ulcer activity of leguminosae plants. Arquivos de Gastroenterologia 51(1):64-68. https://doi.org/10.1590/S0004-28032014000100013

Raskin I, Ribnicky DM, Komarnytsky S, Ilic N, Poulev A, Borisjuk N, ... O'Neal JM (2002). Plants and human health in the twenty-first century. Trends in Biotechnology 20(12):522-531. https://doi.org/10.1016/S0167$7799(02) 02080-2$

Sabiu S, Garuba T, Sunmonu T, Ajani E, Sulyman A, Nurain I, Balogun A (2015). Indomethacin-induced gastric ulceration in rats: protective roles of Spondias mombin and Ficus exasperata. Toxicology Reports 2:261-267. https://doi.org/10.3109/13880209.2015.1029050

Sahoo SK, Sahoo HB, Priyadarshini D, Soundarya G, Kumar CK, Rani KU (2016). Antiulcer activity of ethanolic extract of Salvadora indica (W.) leaves on albino rats. Journal of Clinical and Diagnostic Research 10(9):FF07-FF10. https://doi.org/10.7860/JCDR/2016/20384.8470

Sałaga M., Mosińska P (2017). Pharmacological treatment of peptic ulcer disease. In: Fichna J. (Ed). Introduction to Gastrointestinal Diseases Vol. 2. Springer, Cham. https://doi.org/10.1007/978-3-319-59885-7_5

Salami AT, Odukanmi OA, Faniyan OF, Omayone TP, Olaleye SB (2018). Seeds of Buchholzia coriacea in diet mitigate ischemic reperfusion-induced gastric ulceration in experimental rats. Journal of Dietary Supplements 15(6):84259. https://doi.org/10.1080/19390211.2017.1404544 
Sayehmiri K, Abangah G, Kalvandi G, Tavan H, Aazami S (2018). Prevalence of peptic ulcer in Iran: Systematic review and meta-analysis methods. Journal of Research in Medical Sciences 23:8 https://doi.org.10.4103/jrms.JRMS_1035_16

Sistani K N, Arzi A, Rezaie A, Pashmforoosh M, Kordi F (2019). Gastroprotective effect of zingerone on ethanol-induced gastric ulcers in rats. Medicina 55(3):64. https://doi.org/10.3390/medicina55030064

Takeuchi K, Endoh T, Hayashi S, Aihara T (2016). Activation of muscarinic acetylcholine receptor subtype 4 is essential for cholinergic stimulation of gastric acid secretion: relation to D cell/somatostatin. Frontiers in Pharmacology 7:278. https://doi.org/10.3389/fphar.2016.00278

Zabidi Z, Zainulddin WW, Mamat SS, Din SS, Kamisan FH, Yahya F, ... Somchit MN (2012). Antiulcer activity of methanol extract of Melastoma malabathricum leaves in rats. Medical Principles and Practice 21(5):501-503. https://doi.org/10.1159/000337406

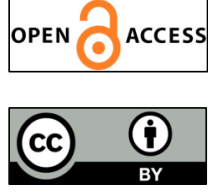

The journal offers free, immediate, and unrestricted access to peer-reviewed research and scholarly work. Users are allowed to read, download, copy, distribute, print, search, or link to the full texts of the articles, or use them for any other lawful purpose, without asking prior permission from the publisher or the author.

License - Articles published in Notulae Scientia Biologicae are Open-Access, distributed under the terms and conditions of the Creative Commons Attribution (CC BY 4.0) License.

(c) Articles by the authors; SHST, Cluj-Napoca, Romania. The journal allows the author(s) to hold the copyright/to retain publishing rights without restriction. 